\title{
Rancang Bangun Prototipe Pengendali Pintu Air Berbasis SMS (Short Message Service) Untuk Pengairan Sawah Menggunakan Arduino
}

\author{
Yanolanda Suzantry Handayani ${ }^{1}$, Adhadi Kurniawan ${ }^{2}$ \\ ${ }^{1}$ Program Studi Teknik Elektro Fakultas Teknik Universitas Bengkulu \\ Email : yanolanda@unib.ac.id \\ ${ }^{2}$ Program Studi Teknik Elektro Fakultas Teknik Universitas Bengkulu \\ Email :Adhadi.k@unib.ac.id
}

\begin{abstract}
ABSTRAK
Currently opening and closing the floodgates for rice fields is still using the manual method, the manual method certainly still requires more effort to do this. Therefore it is necessary to develop a floodgate controller prototype using SMS (Short Message Service) with Arduino as the microcontroller, before making it into a larger form.This research uses experimental research methods. This research was conducted in the robotics laboratory of the Electrical Engineering Study Program, Faculty of Engineering, Bengkulu University. The results of the study, the time to send the fastest SMS when the fields need water is 10.21 seconds and the time to send the fastest SMS when the water needs for the fields is sufficient is 10.00 seconds using the Tri SIM card and the longest time to send SMS when the fields need water is 16.28 seconds and the sending time The longest SMS when the water requirement for rice fields is sufficient is 16.71 seconds using an Indosat SIM card. The performance of the floodgate controller prototype can open and close properly according to the command given via SMS service on the cellphone.

Kata kunci: Module SIM800L, sensor ultrasonic, motor servo, Arduino Uno R3.
\end{abstract}

\section{Pendahuluan}

Teknologi sekarang telah melekat pada kehidupan manusia. Semua pekerjaan manusia hampir seluruhnya menggunakan teknologi bahkan sudah tergantung pada teknologi tersebut. Karena dengan teknologi menjadikan segala sesuatu yang dilakukan menjadi lebih mudah. Hal ini yang mendorong perkembangan teknologi yang telah banyak menghasilkan alat untuk mempermudah kegiatan manusia bahkan menggantikan peran manusia dalam suatu fungsi tertentu.

Berkembangnya teknologi saat ini membantu dan mempermudah kegiatan manusia yang ingin melakukan sesuatu dengan mudah, salah satunya yaitu dalam hal membuka dan menutup pintu air. Pintu air merupakan bangunan penunjang pada suatu bendungan irigasi, sistem pengairan irigasi telah menjadi salah satu cara untuk mengairi persawahan. Jika persediaan air melimpah karena tempat yang dekat dengan sungai atau sumber mata air, maka irigasi dilakukan dengan mengalirkan air tersebut untuk persawahan. Dari sinilah peran pintu air dibutuhkan untuk mengatur debit air yang keluar dari bendungan menuju persawahan. Saat ini membuka dan menutup pintu air untuk persawahan masih menggunakan cara manual, dengan cara manual tentu masih memerlukan usaha secara lebih untuk melakukanya. Maka dari itu perlu dikembangkan sebuah prototipe pengendali pintu air menggunakan SMS (Short Message Service) dengan arduino sebagai mikrokontrolernya, sebelum membuat kedalam bentuk yang lebih besar.

SMS (Short Message Service) adalah sebuah layanan untuk mengirim dan menerima pesan dalam bentuk teks dari dan kepada perangkat mobile ponsel. Teks tersebut bisa terdiri dari kata-kata atau nomor kombinasi alpha numeric. SMS diciptakan sebagai standar pesan (message) oleh ETSI (European Telecommunication Standar Institute) yang juga membuat standar GSM yang diimplementasikan oleh semua operator GSM.

Teknologi SMS memiliki keunggulan Delivered Oriented Service, yaitu pesan akan selalu diusahakan untuk dikirimkan ke tujuan jika suatu saat nomor tujuan tidak aktif atau diluar jangkauan, maka pesan akan disimpan di SMS Center (SMSC) Server yang selanjutnya akan dikirimkan segera setelah nomor tujuan aktif kembali. Setiap penyedia layanan mengoperasikan satu atau lebih SMSC). SMS dari pengguna ponsel dikirim melalui wireless dari menara seluler ke SMSC. Protokol akses SMSC memungkinkan interaksi antara dua SMSC memungkinkan interaksi antara dua SMSC atau interaksi internal antara eksternal Short-Message Entities (SMEs) dan SMS Center [1].

Arduino adalah sebuah rangkaian yang dikembangkan dari mikrokontroler berbasis Atmega328. Arduino uno memiliki 14 kaki digital input atau output, dimana 6 kaki digital diantaranya dapat digunakan sebagai sinyal PWM (Pulse Width Modulation). Sinyal 
PWM berfungsi untuk mengatur kecepatan perputaran motor. Arduino uno memiliki 6 kaki analog input, kristal osilator dengan kecepatan clock $16 \mathrm{MHz}$, sebuah koneksi USB, sebuah konektor listrik, sebuah kaki header dari ICSP, dan sebuah tombol reset yang berfungsi untuk mengulang program [2] [3] [4].

Kelebihan Arduino diantaranya adalah tidak perlu perangkat chip programmer karena didalamnya sudah ada bootloader yang akan menangani upload program dari komputer, Arduino sudah memiliki sarana komunikasi USB, sehingga pengguna laptop yang tidak memiliki port serial atau RS323 bisa menggunakannya. Bahasa pemrograman relatif mudah karena software Arduino dilengkapi dengan kumpulan library yang cukup lengkap, dan Arduino memiliki modul siap pakai (shield) yang bisa ditancapkan pada board Arduino.

Cara membuat hardware pengendali pintu gerbang yaitu dengan menginputkan program untuk mendeteksi ring yang akan menggerakan servo. Dua kali ring untuk menutup gerbang dan dua kali ring selanjutnya untuk menutup. Cara memprogram hardware pengendali pintu adalah dengan menginputkan serangkaian program menggunakan Arduino IDE melalui kabel data Arduino atau kabel serial A to B. Proses kerja dari pengendali pintu gerbang yaitu memanfaatkan panggilan yang akan terdeteksi sebagai ring kemudian Arduino akan memproses ring tersebut untuk menggerakan servo [14].

Pada penelitian yang dilakukan sebelumnya telah dibuat sebuah model kendali pintu air sawah otomatis dengan SIM800L berbasis mikrokontroler arduino uno. Sistem kerja alat ini mampu melakukan buka tutup pintu air pada lahan sawah secara otomatis serta memberikan informasi ketinggian air dengan bantuan sensor water level dan informasi tersebut akan dikirimkan melalui sms kepada petani, Penelitian ini menggunakan 4 mode input sebagai acuan dalam pengoprasian alat yang diantaranya yaitu, mode pengolahan digunakan sebagai acuan level air dalam proses pengolahan lahan sawah, mode penanaman digunakan sebagai acuan level air dalam melakukan proses penanaman padi pada lahan persawahan, mode normal digunakan sebagai acuan level air yang cukup untuk tananam melakukan proses fotosintesis dan mode pupuk digunakan sebagai acuan level air untuk melakukan proses pemupukan tanaman padi. Selain mode tersebut, dapat dilakukan pengontrolan pintu air secara manual dengan cara mematikan alat kendali pintu air otomatis yang digunakan pada lahan pertanian [15].

Dari uraian tersebut maka penulis tertarik untuk melakukan penelitian dengan judul "Rancang Bangun Prototipe Pengendali Pintu Air Menggunakan SMS Untuk Pengairan Sawah Berbasis Arduino"

\section{TINJAUAN PUSTAKA}

\section{A. Perancangan Prototipe Pengendali Pintu 1. Pengertian Prototipe}

Prototipe merupakan suatu bentuk fisik pertama dari suatu objek yang direncanakan dibuat dalam satu proses produksi, mewakili bentuk dan dimensi dari objek yang diwakilinya dan digunakan untuk objek penelitian pengembangan lebih lanjut [5].

Selain itu pengertian prototipe merupakan suatu set perlatan laboratorium yang digunakan sebagai media pendidikan. Prototipe ditujukan untuk menunjang pembelajaran peserta didik dalam menerapkan pengetahuan atau konsep yang diperolehnya pada benda nyata [6].

Pengertian Prototipe lainnya adalah suatu Prototyping adalah suatu pengembangan yang cepat dan pengujian terhadap model kerja (protipe) dari aplikasi baru melalui proses interaksi dan berulang-ulang yang biasa digunakan ahli sistem informasi dan ahli bisnis. Prototyping disebut juga desain aplikasi cepat (rapid application design atau $R A D$ ) karena menyederhanakan dan mempercepat desain sistem [7].

Berdasarkan beberapa pendapat para ahli maka dapat disimpulkan bahwa prototipe adalah suatu bentuk fisik pertama yang mewakili dari objek sebenarnya untuk digunakan sebagai media pembelajaran peserta didik dalam menerapkan pengetahuan atau konsep yang diperolehnya pada benda nyata. Prototyping disebut juga desain aplikasi cepat (rapid application design atau $R A D$ ) karena menyederhanakan dan mempercepat desain sistem.

\section{Pengertian SIM 800L}

SIM800L merupakan suatu modul GSM yang dapat mengakses GPRS untuk pengiriman data ke internet dengan sistem M2M. AT-Command yang digunakan pada SIM800L mirip dengan AT-Command untuk modulmodul GSM sebelumnya. Sehingga jika diinginkan, modul ini dapat diganti dengan modul GSM lain yang mempunyai komunikasi data serial TTL untuk antar muka dengan mikrokontroler [8].

Selain itu pengertian SIM 800L adalah salah satu modul GSM atau GPRS yang bekerja pada frekuensi quad band yaitu GSM850MHz, EGSM900MHz, DCS1800MHz dan PCS1900MHz. Modul ini berkomunikasi secara serial sehingga dapat langsung dihubungkan pada port serial mikrokontroler. GSM SIM800L harus mendapatkan tegangan masuk antara $3,7 \mathrm{v}-4,4 \mathrm{v}$ [9].

SIM800L menurut pendapat lain yaitu modul GSM yang bisa untuk project mikrokontroler seperti monitoring 


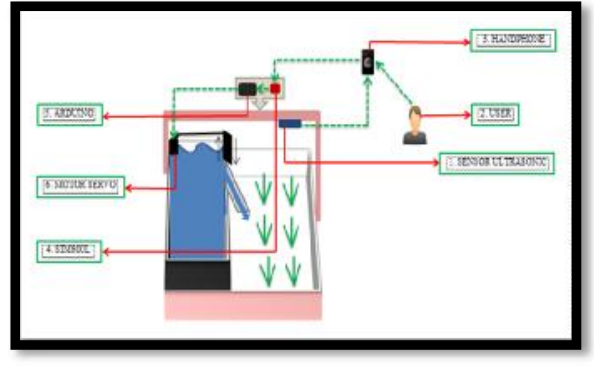

Gambar 1. Diagram Blok Global

melalui SMS, menyalakan atau mengendalikan saklar listrik melalui SMS dan sebagainya. Modul GSM ini juga dapat berfungsi sebagai SMS gateway apabila dihubungkan dengan mikrokontroler [10].

Berdasarkan beberapa pendapat para ahli maka dapat disimpulkan bahwa SIM800L merupakan salah satu modul GSM yang dapat mengakses GPRS untuk pengiriman data ke internet dengan sistem M2M. Modul ini bekerja pada frekuensi quad band yaitu GSM850MHz, EGSM900MHz, DCS1800MHz dan PCS1900MHz.

\section{Pengertian Motor Servo}

Motor sevo adalah sebuah motor dengan sistem closed feedback dimana posisi dari motor akan diinformasikan kembali ke rangkaian kontrol yang ada di dalam motor servo. Motor ini terdiri dari sebuah motor, serangkaian gear, potensiometer dan rangkaian kontrol. Potensiometer berfungsi untuk menentukan batas sudut dari putaran servo [11].

Selain itu pengertian Motor servo adalah motor DC yang dilengkapi dengan sistem kontrol. Sistem kontrol ini akan memberikan umpan balik posisi perputaran motor dari 0 sampai 180 derajat. Disamping itu motor ini juga memiliki torsi relatif cukup kuat. Sistem pengkabelan motor servo terdiri atas 3 bagian, yaitu Vcc, Gnd, dan Kontrol (PWM= Pulse Width Modulation). Pemberian PWM pada motor servo akan membuat servo bergerak pada [12].

Sedangkan menurut pendapat pustaka yang lain Motor servo adalah sebuah motor $D C$ yang dilengkapi rangkaian kendali dengan sistem closed feedback yang

terintegrasi dalam motor tersebut. Pada motor servo posisi putaran sumbu (axis) dari motor akan diinformasikan kembali ke rangkaian kontrol yang ada di dalam motor servo [13].

Berdasarkan beberapa pendapat para ahli maka dapat disimpulkan bahwa motor servo adalah sebuah motor DC dengan sistem umpan balik tertutup dimana posisi rotornya akan diinformasikan kembali kerangkaian kontrol yang ada didalam motor servo. Sistem kontrol ini akan memberikan umpan balik posisi perputaran motor dari 0 sampai 180 derajat.

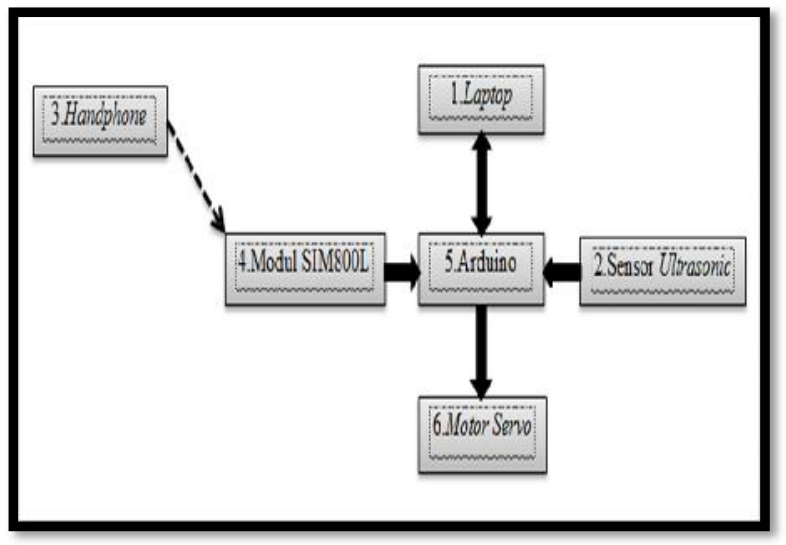

Gambar 2. Digram Blok Rangkaian Alat

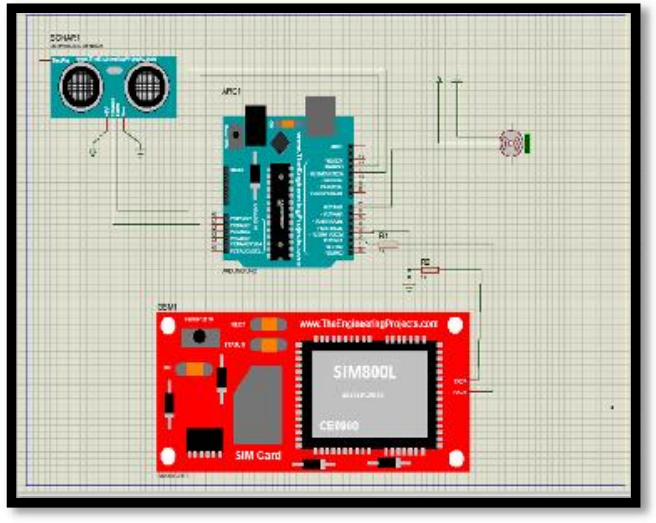

Gambar 3. Desain Rangkaian Alat

\section{B. Metode Penelitian}

Metode penelitian yang digunakan dalam penelitian ini adalah metode eksperimen. Metode penelitian ini bersifat menguji, yaitu analisa waktu yang dibutuhkan untuk membuka pintu air saat layanan sms terkirim dan waktu yang dibutuhkan untuk menutup pintu air saat layanan sms terkirim.

\section{Metode Pengumpulan Data}

Adapun metode pengumpulan data yang digunakan dalam penyusunan laporan penelitian ini adalah sebagai berikut:

1. Studi pustaka

Data penelitian pada metode studi pustaka diperoleh dari sumber pustaka yang meliputi, e-book, jurnal, dan artikel tentang robotik, dan yang menjadi rujukan adalah jurnal ilmiah.

\section{Studi Laboraturium}

Adapun Studi Laboratorium dalam penelitian ini adalah melakukan pengujian secara langsung terhadap kinerja rancang bangun prototipe pengendali pintu air menggunakan SMS untuk pengairan sawah berbasis arduino. 


\section{Metode Perancangan Sistem}

\section{A. Diagram Blok Global}

Diagram blok yang digunakan dalam penelitian ini adalah sebagai berikut :

\section{B. Diagram Blok Rangkaian Alat}

Gambar dibawah ini adalah gambar pengendali pintu air menggunakan SMS untuk pengairan sawah berbasis arduino.

\section{Desain Rangkaian Alat}

Keterangan :

1. Module SIM800L berfungsi sebagai alat penghubung antara alat dengan handphone.

2. Arduino berfungsi sebagai media pengolah data berupa program yang diupload dari laptop dengan menggunakan USB.

3. Motor Servo berfungsi sebagai penggerak pintu air agar dapat membuka dan menutup.

4. Sensor Ultrasonic befungsi sebagai pengukur ketinggian air.

\section{Prinsip Kerja Sistem}

Prinsip kerja prototipe pengendali pintu air menggunakan SMS untuk pengairan sawah berbasis arduino yaitu sensor ultrasonic berfungsi sebagai pengukur ketinggian air, jika ketinggian air kurang dari 3 $\mathrm{cm}$ berarti sawah membutuhkan air, kemudian arduino akan mengirimkan perintah ke module SIM800L untuk mengirimkan informasi ke pengguna bahwa sawah membutuhkan air menggunakan layanan SMS. Kemudian pengguna menggunakan layanan SMS sebagai pengendali prototipe pintu air. Setelah layanan SMS dikirim berupa pesan buka dan diterima oleh module SIM800L yang terdapat pada alat pintu air, maka arduino yang terdapat pada alat pintu air akan mengintruksikan motor servo untuk membuka pintu air. Sebaliknya jika ketinggian air lebih dari $10 \mathrm{~cm}$ berarti kebutuhan air untuk sawah sudah cukup, kemudian arduino akan mengirimkan perintah ke module SIM800L untuk mengirimkan informasi ke pengguna bahwa kebutuhan air untuk sawah sudah cukup menggunakan layanan SMS. Ketika akan menutup pintu air maka pengguna akan mengirim SMS berupa pesan tutup dan diterima oleh module SIM800L yang terdapat pada alat pintu air, maka arduino yang terdapat pada alat pintu air akan mengintruksikan motor servo untuk menutup pintu air.

\section{HASIL DAN PEMBAHASAN}

\section{A. Hasil}

\section{Pembuatan Alat}

Hasil prototipe pengendali pintu air yang telah dibuat.

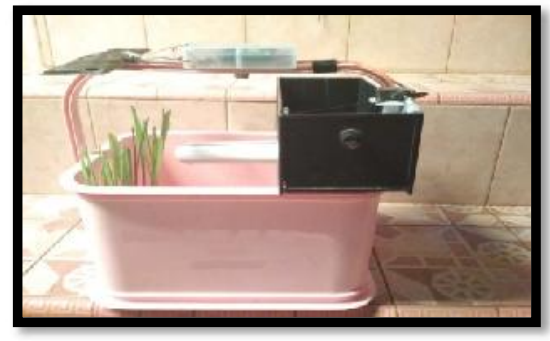

Gambar 4. Prototipe pengendali pintu air.

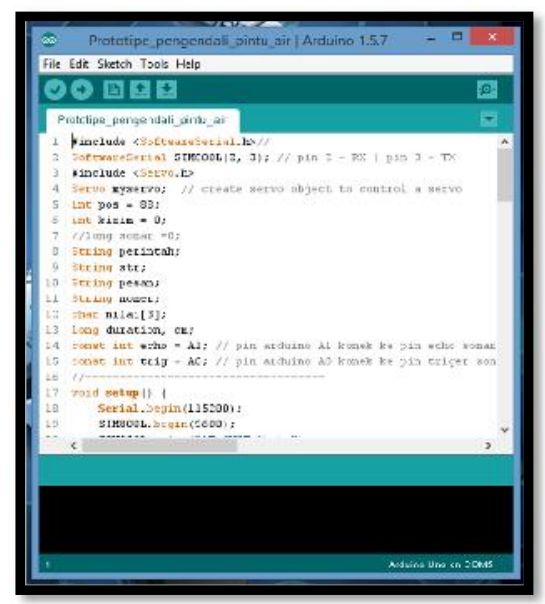

Gambar 5. Hasil program prototipe alat pengendali pintu air.

\section{Hasil Program}

Hasil yang diperoleh dalam menggunakan aplikasi Arduino IDE ini berupa listing program dimana kita akan mengetahui kode program yang akan dikirim dan diterima oleh module SIM800L, yang diupload kedalam mikrokontroller arduino dengan menggunakan laptop. Dalam perancangan prototipe pengendali pintu air yang di upload kedalam arduino dengan menggunakan sebuah laptop dan bahasa pemrograman sketch.

B. Pembahasan

1. Bahan yang digunakan dalam rangkaian alat

Adapun bahan, komponen dan fungsinya yang digunakan dalam merangkai alat yaitu :

1. Mekanik yang terbuat dari bahan plastik.

2. Arduino uno R3 sebagai pengolahan data berupa program yang diupload dari laptop dengan menggunakan USB.

3. Sensor ultrasonic befungsi sebagai pengukur ketinggian air.

4. Module SIM800L berfungsi sebagai alat penghubung antara alat dengan handphone.

5. Motor servo berfungsi sebagai penggerak pintu air agar dapat membuka dan menutup. 


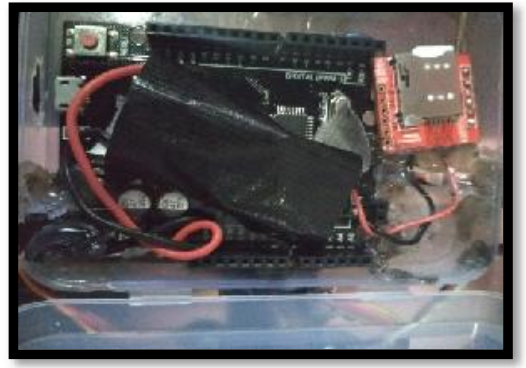

Gambar 6. Hasil rangkaian prototipe pengendali pintu air.

TABEL 1

HASIL PENGUJIAN MODULE SIM800L MENGGUNAKAN KARTU SIM TELKOMSEL

\begin{tabular}{cccc}
\hline \multicolumn{4}{c}{ Waktu yang dibutuhkan dalam } \\
No & $\begin{array}{c}\text { menirim SMS Mengunakan Kartu } \\
\text { SIM Telkomsel Second (S) } \\
\text { Sawah }\end{array}$ & $\begin{array}{c}\text { Kebutuhan air } \\
\text { untuk sawah sudah } \\
\text { Membutuhkan } \\
\text { Air }\end{array}$ & Keterangan \\
\hline 1 & 13.89 & 12.68 & SMS diterima \\
2 & 12.38 & 13.66 & SMS diterima \\
3 & 12.00 & 11.92 & SMS diterima \\
4 & 11.13 & 12.25 & SMS diterima \\
5 & 11.23 & 11.09 & SMS diterima \\
6 & 12.21 & 11.36 & SMS diterima \\
7 & 13.11 & 12.56 & SMS diterima \\
8 & 11.88 & 11.96 & SMS diterima \\
9 & 12.03 & 12.12 & SMS diterima \\
10 & 12.33 & 11.56 & SMS diterima \\
Rata- & 12.219 & 12.116 & SMS diterima \\
rata & & & \\
\hline
\end{tabular}

6. Regulator LM2596 digunakan untuk penstabil agar tegangan module SIM800L dapat bekerja dengan optimal pada tegangan 5 Volt.

\section{Pengujian Prototipe Alat Pengendali Pintu Air}

Dalam pengujian prototipe pengendali pintu air ini penulis melakukan pengujian yang terdiri dari beberapa pengujian yaitu :

1. Pengujian module SIM800L

Dalam Pengujian ini penulis melakukan pengujian terhadap module SIM800L dengan menggunakan kartu SIM Telkomsel, kartu SIM Indosat dan kartu SIM Tri.

2. Pengujian motor servo

Penulis melakukan pengujian terhadap motor servo yaitu waktu yang dibutuhkan untuk membuka pintu air saat layanan SMS terkirim dan waktu yang dibutuhkan untuk menutup pintu air saat layanan SMS terkirim.

3. Pengujian sensor ultrasonic

Penulis melakukan pengujian terhadap sensor ultrasonic yaitu ketepatan sensor ultrasonic mengukur ketinggian air.
TABEL 2

HASIL PENGUJIAN MODULE SIM800L MENGGUNAKAN KARTU SIM INDOSAT

\begin{tabular}{|c|c|c|c|}
\hline \multirow{4}{*}{ No } & \multicolumn{2}{|c|}{$\begin{array}{l}\text { Waktu yang dibutuhkan dalam } \\
\text { mengirim SMS Menggunakan } \\
\text { Kartu SIM Indosat Second (S) }\end{array}$} & \multirow{4}{*}{ Keterangan } \\
\hline & Sawah & Sawah & \\
\hline & Membutuhkan & Membutuhkan & \\
\hline & Air & Air & \\
\hline 1 & 15.10 & 16.70 & SMS diterima \\
\hline 2 & 15.11 & 16.71 & SMS diterima \\
\hline 3 & 13.51 & 15.22 & SMS diterima \\
\hline 4 & 14.19 & 15.95 & SMS diterima \\
\hline 5 & 16.28 & 15.58 & SMS diterima \\
\hline 6 & 14.78 & 14.55 & SMS diterima \\
\hline 7 & 15.56 & 14.77 & SMS diterima \\
\hline 8 & 15.07 & 15.28 & SMS diterima \\
\hline 9 & 15.19 & 15.96 & SMS diterima \\
\hline 10 & 14.76 & 14.12 & SMS diterima \\
\hline Rata-rata & 14.789 & 15.24 & SMS diterima \\
\hline
\end{tabular}

TABEL 3

HASIL PENGUJIAN MODULE SIM800L MENGGUNAKAN KARTU SIM TRI

\begin{tabular}{|c|c|c|c|}
\hline \multirow{2}{*}{ No } & \multicolumn{2}{|c|}{$\begin{array}{l}\text { Waktu yang dibutuhkan dalam } \\
\text { mengirim SMS Menggunakan } \\
\text { Kartu SIM Tri Second (S) }\end{array}$} & \multirow{2}{*}{ Keterangan } \\
\hline & $\begin{array}{c}\text { Sawah } \\
\text { Membutuhkan } \\
\text { Air }\end{array}$ & $\begin{array}{c}\text { Sawah } \\
\text { Membutuhkan } \\
\text { Air }\end{array}$ & \\
\hline 1 & 10.21 & 12.56 & SMS diterima \\
\hline 2 & 10.22 & 10.00 & SMS diterima \\
\hline 3 & 11.21 & 10.33 & SMS diterima \\
\hline 4 & 10.26 & 10.74 & SMS diterima \\
\hline 5 & 10.95 & 11.43 & SMS diterima \\
\hline 6 & 11.12 & 11.55 & SMS diterima \\
\hline 7 & 11.79 & 11.22 & SMS diterima \\
\hline 8 & 11.91 & 11.05 & SMS diterima \\
\hline 9 & 10.71 & 11.43 & SMS diterima \\
\hline 10 & 10.33 & 10.52 & SMS diterima \\
\hline Rata-rata & 10.871 & 11.083 & SMS diterima \\
\hline
\end{tabular}

\section{Hasil Penelitian}

Dari serangkain penelitian yang dilakukan mulai dari awal yaitu masalah yang hendak dibahas sampai dengan hasil pengujian, maka didapat hasil seperti pada tabel dibwah ini :

Berdasarkan tabel 1, pengujian module SIM800L pada prototipe pengendali pintu air dengan menggunakan kartu SIM Telkomsel, waktu mengirimkan SMS tercepat saat sawah membutuhkan air adalah 11.13 detik dan waktu mengirimkan SMS tercepat saat kebutuhan air untuk sawah sudah cukup adalah 11.09 detik, sedangkan waktu mengirimkan SMS terlama saat sawah 
HASIL PENGUJIAN MOTOR SERVO

\begin{tabular}{|c|c|c|c|}
\hline \multirow{2}{*}{ No } & \multicolumn{2}{|c|}{ Waktu Pintu Air Second (S) } & \multirow{2}{*}{ Keterangan } \\
\hline & Membuka & Menutup & \\
\hline 1 & 04.78 & 04.23 & $\begin{array}{c}\text { Pintu air } \\
\text { membuka dan } \\
\text { menutup dengan } \\
\text { cukup baik }\end{array}$ \\
\hline 2 & 04.48 & 03.79 & $\begin{array}{c}\text { Pintu air } \\
\text { membuka dan } \\
\text { menutup dengan } \\
\text { cukup baik }\end{array}$ \\
\hline 3 & 02.97 & 03.24 & $\begin{array}{c}\text { Pintu air } \\
\text { membuka dan } \\
\text { menutup dengan } \\
\text { cukup baik }\end{array}$ \\
\hline 4 & 01.36 & 01.42 & $\begin{array}{c}\text { Pintu air } \\
\text { membuka dan } \\
\text { menutup dengan } \\
\text { cukup baik }\end{array}$ \\
\hline 5 & 02.29 & 02.66 & $\begin{array}{c}\text { Pintu air } \\
\text { membuka dan } \\
\text { menutup dengan } \\
\text { cukup baik }\end{array}$ \\
\hline 6 & 02.79 & 02.88 & $\begin{array}{c}\text { Pintu air } \\
\text { membuka dan } \\
\text { menutup dengan } \\
\text { cukup baik }\end{array}$ \\
\hline 7 & 02.92 & 02.43 & $\begin{array}{c}\text { Pintu air } \\
\text { membuka dan } \\
\text { menutup dengan } \\
\text { cukup baik }\end{array}$ \\
\hline 8 & 03.12 & 03.41 & $\begin{array}{c}\text { Pintu air } \\
\text { membuka dan } \\
\text { menutup dengan } \\
\text { cukup baik }\end{array}$ \\
\hline 9 & 02.29 & 03.07 & $\begin{array}{c}\text { Pintu air } \\
\text { membuka dan } \\
\text { menutup dengan } \\
\text { cukup baik }\end{array}$ \\
\hline 10 & 03.19 & 03.31 & $\begin{array}{c}\text { Pintu air } \\
\text { membuka dan } \\
\text { menutup dengan } \\
\text { cukup baik }\end{array}$ \\
\hline Rata-rata & 03.019 & 03.044 & $\begin{array}{c}\text { Pintu air } \\
\text { membuka dan } \\
\text { menutup dengan } \\
\text { cukup baik }\end{array}$ \\
\hline
\end{tabular}

membutuhkan air adalah 13.89 detik dan waktu mengirimkan SMS terlama saat kebutuhan air untuk sawah sudah cukup adalah 13.66 detik.

Berdasarkan Tabel 2, pengujian module SIM800L pada prototipe pengendali pintu air dengan menggunakan kartu SIM Indosat, waktu mengirimkan SMS tercepat saat sawah membutuhkan air adalah 13.44 detik dan waktu mengirimkan SMS tercepat saat kebutuhan air untuk sawah sudah cukup adalah 14.26 detik, sedangkan waktu mengirimkan SMS terlama saat sawah membutuhkan air adalah 16.28 detik dan waktu mengirimkan SMS terlama saat kebutuhan air untuk sawah sudah cukup adalah 16.71 detik.
HASIL PENGUJIAN SENSOR ULTRASONIC

\begin{tabular}{|c|c|c|c|}
\hline \multirow[b]{2}{*}{ No } & \multicolumn{2}{|c|}{$\begin{array}{l}\text { Ketepatan Sensor Ultrasonic } \\
\text { Mengukur Ketinggian Air }(\mathrm{cm})\end{array}$} & \multirow[b]{2}{*}{ Keterangan } \\
\hline & $\begin{array}{c}\text { Sawah } \\
\text { membutuhkan } \\
\text { air }(3 \mathrm{~cm})\end{array}$ & $\begin{array}{l}\text { Kebutuhan air } \\
\text { untuk sawah } \\
\text { sudah cukup } \\
\quad(10 \mathrm{~cm})\end{array}$ & \\
\hline 1 & $3 \mathrm{~cm}$ & $10 \mathrm{~cm}$ & $\begin{array}{l}\text { Sensor mengukur } \\
\text { ketinggian air dengan } \\
\text { tepat saat sawah } \\
\text { membutuhkan air dan } \\
\text { saat kebutuhan air } \\
\text { untuk sawah sudah } \\
\text { cukup. } \\
\text { Sensor } \\
\text { ketinggian air dengan }\end{array}$ \\
\hline 2 & $3 \mathrm{~cm}$ & $9 \mathrm{~cm}$ & $\begin{array}{l}\text { tepat saat sawah } \\
\text { membutuhkan air dan } \\
\text { sensor tidak mengukur } \\
\text { ketinggian air dengan } \\
\text { tepat saat kebutuhan air } \\
\text { untuk sawah sudah } \\
\text { cukup. }\end{array}$ \\
\hline 3 & $2 \mathrm{~cm}$ & $8 \mathrm{~cm}$ & $\begin{array}{l}\text { Sensor tidak mengukur } \\
\text { ketinggian air dengan } \\
\text { tepat saat sawah } \\
\text { membutuhkan air dan } \\
\text { saat kebutuhan air } \\
\text { untuk sawah sudah } \\
\text { cukup. }\end{array}$ \\
\hline 4 & $2 \mathrm{~cm}$ & $9 \mathrm{~cm}$ & $\begin{array}{l}\text { Sensor tidak mengukur } \\
\text { ketinggian air dengan } \\
\text { tepat saat sawah } \\
\text { membutuhkan air dan } \\
\text { saat kebutuhan air } \\
\text { untuk sawah sudah } \\
\text { cukup. }\end{array}$ \\
\hline
\end{tabular}

Sensor tidak mengukur ketinggian air dengan tepat saat sawah membutuhkan air sedangkan sensor mengukur ketinggian air dengan tepat saat kebutuhan air untuk sawah sudah cukup. Sensor mengukur ketinggian air dengan tepat saat sawah membutuhkan air dan saat kebutuhan air untuk sawah sudah cukup.

Sensor mengukur ketinggian air dengan tepat saat sawah membutuhkan air dan sensor tidak mengukur ketinggian air dengan tepat saat kebutuhan air untuk sawah sudah cukup.

Sensor tidak mengukur ketinggian air dengan tepat saat sawah 


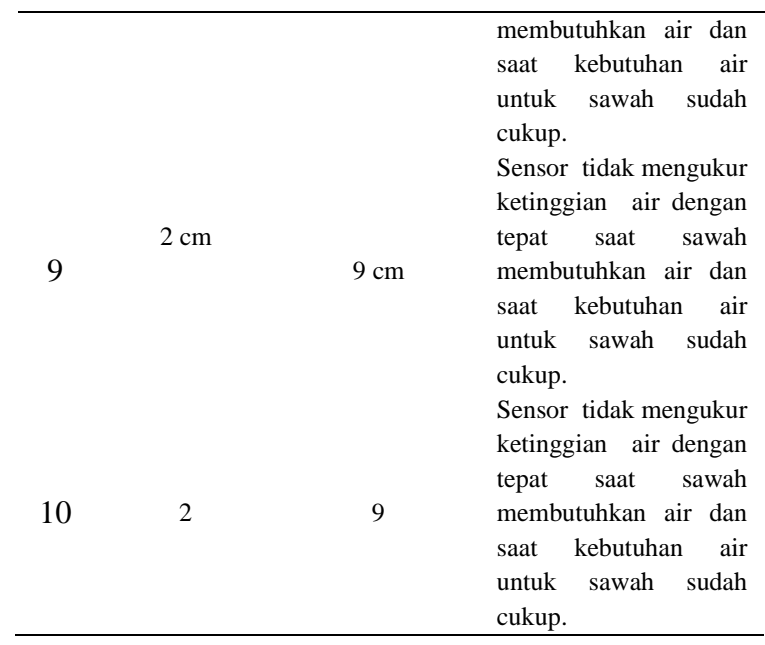

Berdasarkan Tabel 3, pengujian module SIM800L pada prototipe pengendali pintu air dengan menggunakan kartu SIM Tri, waktu mengirimkan SMS tercepat saat sawah membutuhkan air adalah 10.21 detik dan waktu mengirimkan SMS tercepat saat kebutuhan air untuk sawah sudah cukup adalah 10.00 detik, sedangkan waktu mengirimkan SMS terlama saat sawah membutuhkan air adalah 11.91 detik dan waktu mengirimkan SMS terlama saat kebutuhan air untuk sawah sudah cukup adalah 12.56 detik.

Berdasarkan Tabel 4, waktu tercepat pintu air membuka saat layanan SMS terkirim adalah 01.36 detik dan waktu tercepat pintu air menutup saat layanan SMS terkirim adalah 01.42 detik, sedangkan waktu terlama pintu air membuka saat layanan SMS terkirim adalah 04.78 detik dan waktu terlama pintu air menutup saat layanan SMS terkirim adalah 04.23 detik.

Berdasarkan Tabel 5, sensor ultrasonic tidak mengukur ketinggian air dengan tepat saat sawah membutuhkan air sebanyak tujuh kali dari sepuluh kali pengujian dan tiga kali dari sepuluh kali pengujian sensor mengukur ketinggian air dengan tepat saat sawah membutuhkan air, sedangkan sensor ultrasonic mengukur ketinggian air dengan tepat saat kebutuhan air untuk sawah sudah cukup sebanyak enam kali dari sepuluh kali pengujian dan empat kali dari sepuluh kali pengujian sensor tidak mengukur ketinggian air dengan tepat saat kebutuhan air untuk sawah sudah cukup.

Dari pengujian prototipe pengendali pintu air didapatkan hasil bahwa waktu mengirimkan SMS tercepat saat sawah membutuhkan air adalah 10.21 detik dan waktu mengirimkan SMS tercepat saat kebutuhan air untuk sawah sudah cukup adalah 10.00 detik dengan menggunakan kartu SIM Tri dan waktu mengirimkan SMS terlama saat sawah membutuhkan air adalah 16.28 detik dan waktu mengirimkan SMS terlama saat kebutuhan air untuk sawah sudah cukup adalah 16.71 detik dengan menggunakan kartu SIM Indosat, waktu tercepat pintu air membuka saat layanan SMS terkirim adalah 01.36 detik dan waktu tercepat pintu air menutup saat layanan SMS terkirim adalah 01.42 detik, sedangkan waktu terlama pintu air membuka saat layanan SMS terkirim adalah 04.78 detik dan waktu terlama pintu air menutup saat layanan SMS terkirim adalah 04.23 detik dan sensor ultrasonic tidak mengukur ketinggian air dengan tepat saat sawah membutuhkan air sedangkan saat kebutuhan air untuk sawah sudah cukup sensor ultrasonic mengukur ketinggian air dengan tepat.

\section{KESIMPULAN}

1. Waktu mengirimkan SMS tercepat saat sawah membutuhkan air adalah 10.21 detik dan waktu mengirimkan SMS tercepat saat kebutuhan air untuk sawah sudah cukup adalah 10.00 detik dengan menggunakan kartu SIM Tri dan waktu mengirimkan SMS terlama saat sawah membutuhkan air adalah 16.28 detik dan waktu mengirimkan SMS terlama saat kebutuhan air untuk sawah sudah cukup adalah 16.71 detik dengan menggunakan kartu SIM Indosat.

2. Prototipe dapat membuka dan menutup pintu air sesuai dengan perintah yang diberikan melalui layanan SMS pada handphone.

3. Sensor ultrasonic tidak mengukur ketinggian air dengan tepat saat sawah membutuhkan air dan saat kebutuhan air untuk sawah sudah cukup.

\section{DAFTAR PUSTAKA}

[1] Afrina dan Ibrahim. 2015. Pengembangan Sistem Informasi SMS Gateway Dalam Meningkatkan Layanan Komunikasi Sekitar Akademika Fakultas Ilmu Komputer Unsri. Jurnal Sistem Informasi (JSI). Vol. 7 No. 2. 864 halaman.

[2] Ana, Syeh, Aji dan Tatang. 2017. Sistem Pengawasan Penggunaan Gelang Electro Static Discharge (ESD) Berbasis Mikrokontroler Arduino Uno Dan WEB Di PT. Muramoto Elektronika Indonesia. Jurnal Informatika SIMANTIK. Vol. 2 No. 5.58 halaman.

[3] Arasada dan Suprianto. 2017. Aplikasi Sensor Ultrasonic Untuk Mendeteksi Posisi Jarak Pada Ruang Menggunakan Arduino Uno. Jurnal Teknik Elektro. Vol. 06 No.02. 8 halaman.

[4] Arifin, Jauhari, Dkk. 2016. Perancangan murottal otomatis menggunakan mikrokontroler arduino MEGA 2560. Jurnal Media Infotama. Vol. 12 No. 1. 98 halaman.

[5] Fatoni, Ahmad dan Rendra, Dwi, Bayu. 2014. Perancangan Prototype Sistem Kendali Lampu 
Menggunakan Handphone Android Berbasis Arduino. Jurnal PROSISKO. Vol. 1. 29 halaman.

[6] Febriyanto, Fariz, Irwansyah dan Rakhmawati, Lusia. 2016. Pengembangan Media Pembelajaran Prototype CCTV Pada Mata Pelajaran PPPEAV (Perbaikan dan Perawatan Peralatan Elektronika Audio Video) Untuk SMK Negeri 3 Surabaya. Jurnal Pendidikan Teknik Elektro. Vol. 05 No. 03. 1035 halaman.

[7] Nugraha, Susanto dan Nugraha. 2016. Prototype Desaian dan Implementasi Perangkat Pendeteksi Ketinggian Air Laut Berbasis Arduino. e-Proceeding of Engineering. Vol. 3 No.1. 112 halaman.

[8] Wijaya, Sunarya dan Hariyani. 2015. Implementasi Telemetri Pengamatan Profil Cuaca Dan Kualitas Di Gunung Tangkuban Perahu. Jurnal e-Proceeding of Applied Science. Vol. 1 No. 2. 1275 halaman.

[9] Wibowo dan Setyawan. 2017. Security Pengamanan Terhadap Kebocoran Kompor Gas Dengan Pemanfaatan Mikrokontroller Dan GSM ( Global for Sistem Mobile Communication). Jurnal Teknik Komputer. Vol. 3 No. 2. 103 halaman.

[10] Gusmanto, Marindani dan Sanjaya. 2016. Rancang Bangun Sistem Peringatan Dini Dan Pelacakan Pada Kendaraan Sepeda Motor Dengan
Menggunakan Mikrokontroler Arduino nano. Jurnal Universitas Tanjungpura. Vol. 1 No. 1. 11 Halaman.

[11] Nasution, Putri dan Hariyani. 2015. Perancangan Implementasi Tuner Gitar Otomatis Dengan Penggerak Motor Servo Berbasis Arduino. Jurnal Elektro Telekomunikasi Terapan . Vol. 1 No.1. 94 halaman.

[12] Giant, Darjat dan Sudjadi. 2015. Perancangan Aplikasi Pemantau dan Pengendali Piranti Elektronik Pada Ruangan Berbasis WEB. Jurnal eISSN. Vol. 17 No. 2.75 halaman.

[13] Radhan dan Hizriani. 2017. Perancangan Alat PenyortirPermen Berdasarkan Perbedaan Warna Menggunakan Sensor RGB LED Berbasis Mikrokontroler Arduino Uno. Jurnal Manajemen Informatika dan Teknik Komputer. Vol. 2 No.1. 10 halaman.

[14] Rahan, arif dan Wibowo, Wahyu, Ferry. 2015. Prototip Sistem Pengendali Pintu Gerbang Berbasis Missed Call Menggunakan Arduino Uno. Jurnal Teknik Informatika STMIK AMIKOM Yogyakarta. Vol. 1 No.1. 03 halaman.

[15] Dharma, Lingga, Putu, I dan Tansa, Salmawaty dan Nasibu, Zulkarnain, Iskandar. 2019. Perancangan Alat Pengendali Pintu Air Sawah Otomatis Dengan SIM800I Berbasis Mikrokontroller Arduino Uno. Jurnal Teknik Vol. 17 No.1. 16 halaman. 